\title{
Pola Pergerakan Perilaku Agonistik Lobster Air Tawar Cherax quadricarinatus (Von Martens, 1868)
}

\author{
Movement Patterns of Agonistic Behaviour of Crayfish Cherax quadricarinatus (Von \\ Martens, 1868)
}

\author{
Tarjono ${ }^{1}$ dan Mufti P. Patria*
}

Program Studi Pascasarjana, Departemen Biologi FMIPA-UI, Depok

${ }^{1}$ Alamat sekarang: SMPN 181, Karet Tengsin, Tanah Abang, Jakarta Pusat

E-mail: mpatria@ui.ac.id* penulis untuk korespondensi

\begin{abstract}
This research on movement patterns of agonistic behavior in crayfish Cherax quadricarinatus was conducted at laboratory and used an aquarium size $25 \mathrm{~cm} \times 10 \mathrm{~cm} \times 15 \mathrm{~cm}$. The patterns of agonistic behavior were recorded by using a CCD and digital camera. The recorded data were analyzed using The Adobe Premier computer program and using Jaccard similarity to solve the reciprocal movement patterns. Clustering based on the UPGMA (Unweighted Pair Group Method Average) indicated that the dissimilarity value was about 0,98 and the moving pattern of the agonistic behaviors were grouped into five groups, namely: 1) threatening; 2) arranging the strategy; 3) testing the enemies capability; 4) fighting; 5) avoiding and defending.
\end{abstract}

Key words: Agonistic behaviour, Cherax quadricarinatus, conspecifics, video analysis

\begin{abstract}
Abstrak
Penelitian pola pergerakan perilaku agonistik pada lobster Cherax quadricarinatus telah dilakukan di laboratorium dengan menggunakan akuarium ukuran $25 \mathrm{~cm}$ x $10 \mathrm{~cm}$ x $15 \mathrm{~cm}$. Pola perilaku agonistik direkam dengan menggunakan kamera CCD dan digital. Data hasil rekaman dianalisis dengan menggunakan program komputer Adobe Premier dan kesamaan Jaccard untuk memecahkan pola gerakan yang resiprok (timbal balik). Clustering berdasarkan UPGMA (Unweighted Pair Group Method Average) menunjukkan bahwa nilai ketidaksamaan sekitar 0,98 dan terdapat lima kelompok pola pergerakan dari perilaku agonistik, yaitu: 1) mengancam, 2) menyusun strategi; 3) menguji kemampuan musuh; 4) melawan; 5) menghindari dan membela.
\end{abstract}

Kata kunci: Perilaku agonistik, Cherax quadricarinatus, satu jenis, analisis video

Diterima: 16 Juni 2010, disetujui: 16 Oktober 2010

\section{Pendahuluan}

Cherax quadricarinatus (Von Martens, 1868) (Decaposa, Parastacidae) adalah salah satu lobster air tawar (LAT) yang berasal dari Australia dengan memiliki toleransi yang luas terhadap parameter kualitas air, pada kisaran suhu $10^{\circ}-35^{\circ} \mathrm{C}$, kadar oksigen minimum $1 \mathrm{ppm}$, pH 6-9,5, salinitas tertinggi $12 \mathrm{ppt}$, dan kadar amonia 1 ppm (Jones, 1998). Tubuhnya, berwarna biru metalik sehingga hewan tersebut banyak dibudidaya di Indonesia sebagai udang hias. Hewan tersebut termasuk omnivora dan memiliki sifat kanibalisme yang sudah dimulai sejak dalam stadia juwana, terutama ketika selesai molting (ganti kulit). Oleh karena itu, $C$. quadricarinatus memerlukan tempat persembunyian agar dapat terlindung dari serangan LAT lain selama proses molting berlangsung (Bergman dan Moore, 2003; Alonso dan Martínez, 2006). Seluruh LAT memiliki perilaku agonistik yang kuat dalam mendapatkan sumber daya seperti ruang, makanan, dan pasangan (Herberholz et al., 2007). Interaksi agonistik ditunjukkan LAT tidak hanya terhadap spesies yang sama tetapi juga terhadap spesies lain (Nakata dan Goshima, 2003).

Sifat agonistik pada pertarungan LAT diawali dengan mengangkat tubuh oleh kaki 
jalan, ekor mengembang, kemudian menyentuh lawan dengan capit terbuka mengancam lawan yang mendekatinya (Breithaupt dan Eger, 2002). Apabila lawan terus mendekat maka capit yang terbuka tersebut digunakan untuk mencengkram lawan dan apabila keduanya tidak ada yang mundur maka pertarungan pun akan berlangsung. Pertarungan terjadi dengan cara saling mendorong dan saling mencengkeram pada bagian capit, kaki, maupun antena, kadang diiringi dengan saling pukul menggunakan antena atau capit (Bergman dan Moore, 2003). Pertarungan akan terus berlangsung sehingga ada salah satu lawan yang mundur atau menghindar (Huber dan Kravitz, 1995; Bergman dan Moore, 2003).

Lobster air tawar yang keluar sebagai pemenang dalam pertarungan akan menunjukkan perilaku dominan terhadap lawannya yaitu selalu menyerang dengan capit diangkat dalam keadaan terbuka. Sebaliknya, LAT yang kalah akan berperilaku subordinat atau non-agonistik seperti bergerak mundur, menghindar dari pertemuan dengan lawannya dan melakukan tailflip secara terus menerus atau bersikap tunduk (Breithaupt dan Eger, 2002; Herberholz et al., 2003; Bergman dan Moore, 2003).

Penelitian agonistik LAT telah dilakukan pada jenis Homarus americanus (Huber dan Kravitz, 1995) Cambaroides japonicus dan Pasifastacus leniusculus (Nakata dan Goshima, 2003), Orconectes rusticus dan Orconectes virilis (Bergman dan Moore, 2003), serta Procambarus clarkii (Breithaupt dan Eger, 2002; Herberholz et al., 2003). Akan tetapi, perilaku agonistik Cherax quadricarinatus hasil budidaya bukan di daerah asalnya belum banyak diteliti. Tujuan penelitian ini untuk mendeskripsikan pola pergerakan agonistik LAT (conspecifics bouts), sehingga dapat menjadi tambahan referensi tentang biologi perilaku hewan introduksi tersebut.

\section{Metode Penelitian}

Penelitian dilakukan dan bulan Maret sampai Mei 2009 berlokasi di rumah kaca, Departemen Biologi, Fakultas MIPA-UI, Depok.

\section{Alat dan Bahan}

Alat yang digunakan dalam penelitian adalah satu akuarium berukuran $40 \mathrm{~cm}$ x $100 \mathrm{~cm}$ x $30 \mathrm{~cm}$, untuk penuaan air; satu akuarium pertarungan berukuran $25 \mathrm{~cm} \times 10 \mathrm{~cm} \times 15 \mathrm{~cm}$ yang dasarnya dilapisi karpet dan dibuat arena untuk bertarung; enam akuarium $(50 \mathrm{~cm}$ x $20 \mathrm{~cm}$ x $30 \mathrm{~cm}$ ), tiap-tiap akuarium disekat dengan lembaran plastik tidak tembus pandang menjadi 10 ruang untuk meletakkan hewan uji; satu aerator AC-9902 50Hz 5W; selang untuk pembagian aerasi $(6 \mathrm{~m})$; timbangan (Ohaus); penggaris $30 \mathrm{~cm}$; satu kamera digital Sony Cyber-shot DSC-F88; satu kamera CCD model No.SJA-642; satu set TV turner untuk menghubungkan kamera CCD dengan Laptop; satu Lightweight Tripod; dan satu laptop Toshiba Satellite A135-S2276 untuk menyimpan data hasil percobaan.

Bahan-bahan yang diperlukan adalah 30 ekor LAT yang diketahui usia, jenis kelamin, dan tahap molting diperoleh dari pembudidaya yang berbeda tempatnya yaitu 20 ekor dari Bintaro Fish Center (BFC) dan 10 ekor dari pembudidaya LAT di Bogor. Hal tersebut dilakukan untuk menghindari adanya pengalaman bertarung di antara hewan uji; air sebagai media yang telah dibiarkan di dalam akuarium selama 24 jam (dituakan).

\section{Cara Kerja}

\section{Aklimasi dan Pencatatan Data LAT}

Lobster air tawar dimasukkan ke dalam akuarium yang telah disekat-sekat dengan lembaran plastik tidak tembus pandang. Setiap sekat diisi satu ekor hewan uji. Hewan uji diaklimasi selama 72 jam, kemudian dicatat panjang dan berat tubuh serta jenis kelamin dan tahap molting.

\section{Percobaan Perilaku Agonistik}

Pertarungan dilakukan satu lawan satu berdasarkan kesamaan berat dan masa molting sedangkan jenis kelamin dari kedua jenis udang tersebut diacak, karena pertarungan yang terjadi di alam tidak terjadi pada hewan yang sama jenis kelaminnya. Akuarium untuk pertarungan disekat menjadi tiga ruangan. Sekat dapat dibuka ketika hewan akan ditarungkan. Pasangan LAT yang akan ditarungkan dimasukkan ke dalam ruangan yang berbeda, yaitu LAT BFC dimasukan ke dalam ruang sisi satu dan LAT Bogor ke dalam ruang sisi lainnya. Sekat pembatas diangkat sehingga LAT memasuki 
arena pertarungan (Gambar 1). Hewan yang dinyatakan kalah yaitu hewan yang melakukan tailflip atau mundur secara terus menerus dan selalu menghindar dari serangan musuh. Lama pengamatan untuk setiap pasangan yang bertarung dilakukan paling lama 20 menit atau tergantung pada waktu sampai kapan kedua hewan tersebut bertarung dan ada yang kalah.

Seluruh percobaan dilaksanakan dari jam 18.00 sampai jam 24.00 setiap malam karena hewan uji bersifat nokturnal. Aktivitas pertarungan direkam dari atas dan dari depan menggunakan kamera CCD model No.SJA-642 dan kamera digital Sony Cyber-shot DSC-F88, kemudian data hasil rekaman tersebut disimpan dalam hardisk sebuah laptop Toshiba Satellite A135-S2276 untuk dianalisis lebih lanjut.

\section{Analisis data}

Video hasil rekaman dikuantifikasi menggunakan software Adobe Premier Pro. Dengan program tersebut, setiap pergerakan yang dilakukan hewan uji dapat dihitung setiap detik. Pola pergerakan perilaku agonistik hewan uji yang sedang bertarung didefinisikan ke dalam 16 variabel (Tabel 1).

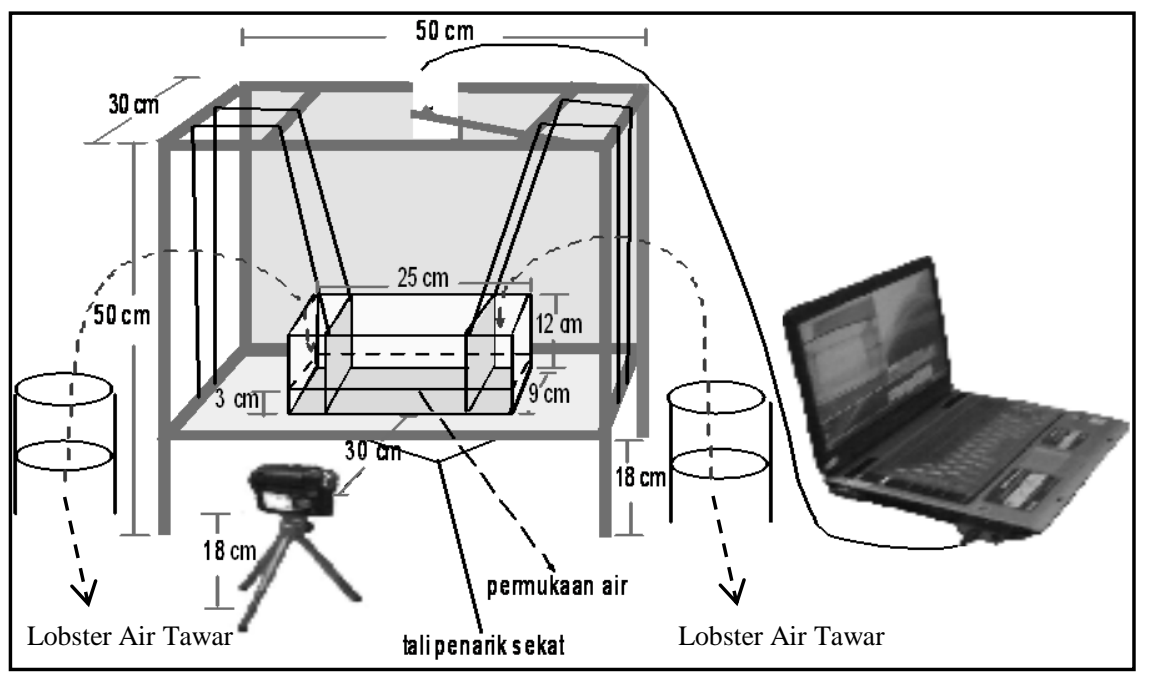

Gambar 1. Rangkaian alat yang digunakan untuk percobaan perilaku agonistik LAT.

Tabel 1. Definisi variabel pola pergerakan perilaku agonistik.

\begin{tabular}{cll}
\hline \hline Kode & \multicolumn{1}{c}{ Pola Pergerakan } & \multicolumn{1}{c}{ Keterangan } \\
\hline \hline A & Menyergap & Menyergap lawan secara cepat \\
B & Mundur & Bergerak mundur menghindari pertemuan dengan lawan \\
C & Tailflip & Bergerak salto sebagai respon terhadap sergapan lawan \\
D & Badan diangkat & Badan diangkat ke atas oleh kaki jalan \\
E & Angkat capit & Capit diangkat sebagai ancaman terhadap lawan \\
F & Turunkan capit & Capit diturunkan takut ancaman lawan \\
G & Menyentuh tertutup & Menyentuh lawan dengan capit tertutup \\
H & Menyentuh terbuka & Menyentuh lawan dengan capit terbuka \\
I & Mencengkram & Capit mencengkram lawan \\
J & Memukul & Memukul dengan capit \\
K & Capit menangkis & Capit menangkis sentuhan/pukulan lawan \\
L & Angkat sefalotoraks & Sefalotoraks diangkat menghindari cengkraman pada daerah rahang \\
M & Turunkan sefalotoraks & Sefalotoraks diturunkan karena lawan tidak mencengkram daerah rahang \\
N & Antena lurus & Antena diangkat lurus ke atas \\
O & Antena menangkis & Menangkis cambukan antena lawan \\
P & Antena mencambuk & Antena mencambuk lawan \\
\hline \hline
\end{tabular}


Enam belas variabel pola pergerakan yang dihitung di antaranya terdapat pola yang dilakukan bersama oleh kedua hewan yang sedang bertarung. Kegiatan yang diulang-ulang terjadi bersama-sama dalam interval waktu satu detik diasosiasikan sebagai pola yang sama (Huber dan Kravitz, 1995). Untuk mengevaluasi beberapa kegiatan yang dilakukan bersama oleh hewan uji digunakan analisis statistik dengan mengukur indeks kesamaan Jaccard (Prosedur PROXIMITIES; SPSS Inc., 2004). Pengukuran indeks kesamaan Jaccard ialah untuk menemukan hubungan dua pola pergerakan yang dilakukan oleh kedua LAT, berdasarkan ada atau tidaknya pasangan pola pergerakan tersebut.

Perhitungan kesamaan Jaccard $(\mathrm{x}, \mathrm{y})=$

$$
\frac{\sum(\mathrm{a} \text { dan } \mathrm{b})}{\left.\sum(\text { hanya } \mathrm{a})+\sum \text { (hanya } \mathrm{b}\right)+\sum(\mathrm{a} \text { dan } \mathrm{b})}
$$

Keterangan : pasangan variabel $(a, b)$ yaitu pasangan variabel yang dilakukan hewan uji pada saat bertarung. Misalnya $\mathrm{a}=\mathrm{H}$ (menyentuh dengan capit terbuka), $\mathrm{b}=\mathrm{K}$ (menangkis dengan capit).

Berapa kali hewan A dan B hanya melakukan $\mathrm{K}$, hanya melakukan $\mathrm{H}$, dan berapa kali melakukan $\mathrm{H}$ dan $\mathrm{K}$ yang datanya diperoleh dari hasil kuantifikasi menggunakan Adobe Premier Pro. Hasil kesamaan Jaccard kemudian dibuat cluster menggunakan program MVSP (Multi-Variate Statistical Package) versi 3.1 dengan Clustering berdasarkan UPGMA (Unweighted Pair Group Method Average), dapat dihasilkan dendogram yang membagi pola pergerakan perilaku agonistik menjadi beberapa kelompok.

\section{Hasil dan Pembahasan}

Pertarungan antara LAT yang berasal dari Bintaro Fish Center (BFC) dan LAT yang dari Bogor 70\% dimenangkan oleh LAT yang berasal dari Bogor (Tabel 2). Empat pertarungan pasangan LAT jantan dengan betina, telah dimenangkan oleh betina pada tiga pertarungan.

Pola pergerakan perilaku agonistik lobster air tawar ditunjukkan adanya perubahan sikap tubuh seperti badan diangkat oleh kaki jalan, abdomen diangkat, antena digerakan tegak lurus ke atas, atau capit menyentuh lawan. Aktivitas penggunaan capit untuk menyentuh lawan, antena diangkat tegak lurus atau mencambuk lawan tampak paling sering dilakukan LAT yang sedang bertarung (Gambar 2).

Pola pergerakan yang sama yang dilakukan oleh kedua hewan dalam tiap interval waktu satu detik dihitung dan diukur tingkat kedekatannya dengan dibuat matriks Jaccard similarity (Gambar 3). Pola pergerakan agonistik antara hewan dominan dan subordinat terdapat pola yang bersifat resiprokal. Pola pergerakan tersebut memiliki tingkat kesamaan yang tinggi, yakni perilaku: antena diangkat lurus ke atas $(\mathrm{N} 1, \mathrm{~N} 2)=0,68$; menangkis dan mencambuk lawan dengan antena $(\mathrm{P} 1, \mathrm{O} 2)=0,58,(\mathrm{P} 2, \mathrm{O} 1)=$ 0,37; menyentuh dan menangkis dengan capit terbuka $(\mathrm{H} 1, \mathrm{~K} 2)=0,42,(\mathrm{H} 2, \mathrm{~K} 1)=0,38$; menyergap dan mundur $(\mathrm{A} 1, \mathrm{~B} 2)=0,23$, $(\mathrm{A} 2, \mathrm{~B} 1)=0,15$; mengangkat badan dengan kaki jalan $(\mathrm{D} 1, \mathrm{D} 2)=0,22$; menyentuh dengan capit terbuka dan mundur $(\mathrm{H} 1, \mathrm{~B} 2)=0,16,(\mathrm{H} 2, \mathrm{~B} 1)=$ 0,12 ; mencambuk dengan antena $(\mathrm{P} 1, \mathrm{P} 2)=0,13$; mencengkram dan tailflip (I1,C2) $=0,13,(\mathrm{I} 2, \mathrm{C} 1)$ $=0,07$; menyergap dan mundur $(\mathrm{A} 1, \mathrm{C} 2)=0,12$, $(\mathrm{A} 2, \mathrm{C} 1)=0,04$; dan mencengkram $(\mathrm{I} 1, \mathrm{I} 2)=0,11$.

Hasil kuantifikasi menggunakan Program Adobe Premier Pro terhadap pola pergerakan perilaku agonistik antar LAT menunjukkan bahwa perilaku menyentuh bagian ventral sefalotoraks lawan dengan capit, menyebabkan sefalotoraks tiap-tiap LAT diangkat. Besar sudut sefalotorak yang terangkat terhadap sumbu tubuh (Gambar 4) rata-rata sebesar 69,5\%. Selain itu abdomen juga diangkat sehingga membentuk sudut rata-rata sebesar $26^{\circ}$ dengan sumbu tubuh (Gambar 5). Perilaku mengangkat badan oleh kaki jalan menyebabkan perubahan jarak tubuh dengan substrat $0,77 \mathrm{~mm}$. Kecepatan tailflip yang dilakukan LAT untuk menghindar lawan rata-rata sebesar $54 \mathrm{~mm} /$ detik (Tabel 3). Hewan yang kalah dalam pertarungan akan selalu menghindar atau merapatkan tubuh ke dasar akuarium (Gambar 6).

Hasil uji cluster menggunakan program MVSP (Multi-Variate Statistical Package) versi 3.1 dengan Clustering berdasarkan UPGMA (Unweighted Pair Group Method Average) dihasilkan dendogram yang membagi pola pergerakan perilaku agonistik menjadi lima kelompok. Kelompok I (Mengancam) ialah aktivitas penggunaan antena untuk mencambuk, 
menangkis dan mengangkat antena tegak lurus; Kelompok II (Mengatur strategi) ialah menurunkan sefalotoraks, dan menurunkan capit; Kelompok III (Menguji kemampuan lawan) ialah mengangkat capit dan menyentuh lawan dengan capit tertutup; Kelompok IV (Bertarung) ialah memukul dengan capit, mencengkram, tailflip, menyentuh dengan capit terbuka, menangkis, menyergap, dan mundur; dan Kelompok V (Menghindar dan bertahan) ialah mengangkat sefalotoraks dan badan, menangkis dan menyentuh dengan capit terbuka, mundur, dan menyergap. Pembagian tersebut berdasarkan Jaccard's coefficient dengan nilai kesamaan sekitar 0,02. (Gambar 7). Pola pergerakan dengan nilai positif yang besar ditunjukkan oleh dendogram mengindikasikan bahwa pola tersebut sering dilakukan sedangkan nilai positif yang rendah mengindikasikan aktivitas yang jarang dilakukan.

Antena merupakan anggota badan (appendages) yang penting bagi kelompok Decapoda dalam perilaku agonistik (Tautz 1987; Breithaupt et al., 1995; Smith dan Dunham 1995). Pada Decapoda tidak bercapit seperti spiny lobster antena berfungsi sebagai alat pertahanan (Wilkens et al., 1996). Oleh karena itu dalam pertarungan antena merupakan salah satu organ tubuh yang paling sering digunakan baik untuk mencambuk, mengancam, maupun untuk mendeteksi keberadaan lawan. Pada lobster yang mengalami ablasi antena lebih jarang merespons serangan yang datang dari arah samping atau belakang (Smith dan Dunham, 1995). Hasil pengamatan yang pernah dilakukan Huber dan Kravitz (1995) menunjukkan bahwa aktivitas penggunaan antena pada lobster yang sedang bertarung memiliki nilai kesamaan yang besar. Penggunaan antena untuk mencambuk lawan sering dilakukan oleh kedua LAT yang sedang bertarung baik yang dominan maupun subordinat. Intensitas penggunaan antena untuk mencambuk lebih tinggi dilakukan oleh LAT yang dominan sedang subordinat intensitasnya lebih tinggi pada aktivitas menangkis.

Capit pada kelompok lobster air tawar merupakan senjata utama dalam pertarungan (Huber dan Kravitz, 1995; Goessmann et al., 2000; Bergman dan Moore, 2003; Bergman et al., 2003; Nakata dan Goshima, 2003). Organ tersebut sering digunakan secara bersama oleh kedua hewan yang sedang bertarung dengan tingkat kesamaan yang cukup besar. Besarnya kesamaan aktivitas perilaku menggunakan capit untuk menyentuh dan menangkis pada LAT yang sedang bertarung pernah diamati oleh Huber dan Kravitz (1995) pada pertarungan antar juvenil lobster Amerika (Homarus americanus L.). Aktivitas menyentuh lawan dengan capit terbuka lebih sering dilakukan LAT dominan, sedangkan subordinat lebih sering menangkis sentuhan capit lawannya yang dominan.

Pertarungan tidak hanya ditunjukkan oleh aktivitas capit menyentuh dan menangkis tetapi juga memukul dan mencengkram. Hewan yang anggota tubuhnya dicengkram lawan akan berusaha membebaskan diri dengan melakukan tailflip. Tailflip tidak hanya dilakukan hewan subordinat tetapi juga oleh hewan dominan dalam menghindari sergapan atau cengkraman lawan. Hewan subordinat dalam pertarungan lebih sering melakukan tailflip dibanding hewan dominan (Huber dan Kravitz, 1995; Herberholz et al., 2003).

Pangkal anggota gerak LAT adalah bagian yang paling rawan putus, sehingga LAT sering mengangkat badannya untuk menghindari cengkraman lawan. Aktivitas mengangkat badan dengan kaki jalan juga ditunjukkan LAT sebagai sikap agonistik dalam menghadapi lawan (Huber dan Kravitz, 1995). Cengkraman capit ketika hewan bertarung dapat berakibat fatal karena dapat menyebabkan kerusakan, bahkan putus pada organ yang dicengkram jika lawannya melakukan tailflip dengan kuat (Bergman dan Moore, 2003; Bergman et al., 2003).

Lobster air tawar pada saat bertarung akan melindungi bagian-bagian tubuhnya yang rawan dengan cara menangkis atau mengelak dengan mengangkat organ yang disentuh lawan. Misalnya LAT akan mengangkat sefalotoraksnya jika daerah tersebut disentuh atau dicengkram oleh lawannya karena pada bagian tersebut terdapat organ tubuh yang vital misalnya organorgan pencernaan dan antena (Huxley, 1977; Tautz, 1987). Badan LAT juga akan diangkat ketika lawan menyentuh bagian kaki. Aktivitas mengangkat sefalotoraks atau badan tidak hanya untuk mengelak dari cengkraman lawan tetapi sering dilakukan sebagai perilaku agonistik oleh LAT dominan (Huber dan Kravitz, 1995). 
Clustering pola pergerakan resiprokal pada conspecifics bouts antar LAT menggunakan program MVSP versi 3.1 membentuk lima cluster pola pergerakan, yakni Kelompok I (Mengancam) ialah aktivitas penggunaan antena untuk mencambuk, menangkis dan mengangkat antena tegak lurus; Kelompok II (Mengatur strategi) ialah menurunkan sefalotoraks, dan menurunkan capit; Kelopok III (Menguji kemampuan lawan) ialah mengangkat capit dan menyentuh lawan dengan capit tertutup; Kelompok IV (Bertarung) ialah memukul dengan capit, mencengkram, tailflip, menyentuh dengan capit terbuka, menangkis, menyergap, dan mundur; Kelompok V (Menghindar dan bertahan) ialah mengangkat sefalotoraks dan badan, menangkis dan menyentuh dengan capit terbuka, mundur, dan menyergap. Clustering pada pertarungan serupa pernah dilakukan oleh Huber dan Kravitz (1995) berdasarkan Principal Component Analysis (PCA) menghasilkan enam kelompok pola pergerakan yakni Meral Spread, Wrestling, Do-si-do, Retreat, Antenna Tap, dan Strike/Rip.
Kehadiran LAT sebagai hewan allochthonous species dalam perairan telah banyak mengganggu spesies lokal mulai dari ikan sampai amfibi, bahkan hewan avertebrata lain (Bergman et al., 2003; Griffiths et al., 2004). Tubuh LAT dilengkapi dengan senjata berupa capit yang besar dan kuat sehingga mampu mengalahkan spesies lain dalam kompetisi untuk mendapatkan sumber daya (Hill dan Lodge, 1999; Nakata dan Goshima, 2000; Usio et al., 2001; Griffiths et al., 2004; Rabalais dan Magoulick, 2006). Lobster air tawar juga dapat menjadi predator pada spesies lain seperti ikan, amfibi, dan avertebrata lain yang ada di perairan setempat (Olsson, 2005). Correira (2003) menyatakan bahwa LAT dapat dinyatakan sebagai hama karena sering merusak sistem irigasi, misalnya Procambarus clarkii yang diintroduksi di Portugal pada akhir tahun 70-an capitnya yang kuat tidak hanya digunakan sebagai senjata dalam pertarungan tetapi sering juga digunakan untuk menggali lubang sebagai tempat persembunyiannya.

Tabel 2. Berat, ukuran, jenis kelamin, asal LAT serta pemenang pada percobaan perilaku agonistik.

\begin{tabular}{|c|c|c|c|c|c|c|c|}
\hline \multirow{2}{*}{ No } & \multicolumn{3}{|c|}{ LAT dari BFC (A) } & \multicolumn{3}{|c|}{ LAT dari Bogor (B) } & \multirow{2}{*}{ Menang } \\
\hline & Berat (gram) & Ukuran (cm) & Kelamin & Berat (gram) & Ukuran $(\mathrm{cm})$ & Kelamin & \\
\hline 1 & 5,90 & 6,10 & Jantan & 6,20 & 6,20 & Jantan & B \\
\hline 2 & 6,15 & 6,00 & Betina & 6,00 & 6,00 & Betina & $\mathrm{B}$ \\
\hline 3 & 5,30 & 5,70 & Betina & 5,30 & 5,70 & Jantan & $\mathrm{B}$ \\
\hline 4 & 6,40 & 6,00 & Betina & 5,85 & 6,00 & Betina & A \\
\hline 5 & 5,25 & 5,90 & Jantan & 5,50 & 5,90 & Betina & $\mathrm{B}$ \\
\hline 6 & 5,40 & 5,90 & Jantan & 5,30 & 5,80 & Betina & B \\
\hline 7 & 5,60 & 5,90 & Jantan & 5,90 & 5,80 & Jantan & B \\
\hline 8 & 4,60 & 5,60 & Jantan & 4,93 & 5,70 & Betina & $\mathrm{B}$ \\
\hline 9 & 5,60 & 5,90 & Jantan & 5,80 & 6,00 & Jantan & A \\
\hline 10 & 5,30 & 5,70 & Jantan & 4,70 & 5,60 & Jantan & A \\
\hline
\end{tabular}

Tabel 3. Besar sudut ketika sefalotoraks atau abdomen diangkat, jarak antara badan dan substrat ketika badan diangkat, kecepatan tailflip pada pertarungan antar LAT (hewan dominan dan subordinat).

\begin{tabular}{|c|c|c|c|c|}
\hline \multirow{2}{*}{$\begin{array}{l}\text { Pasangan } \\
\text { ke- }\end{array}$} & \multicolumn{2}{|c|}{$\begin{array}{c}\text { Sudut Elevasi } \\
\end{array}$} & \multirow{2}{*}{$\begin{array}{c}\text { Jarak Badan dan Substrat } \\
\text { Ketika Badan Diangkat } \\
(\mathbf{m m})\end{array}$} & \multirow{2}{*}{$\begin{array}{c}\text { Kecepatan tailflip } \\
(\mathbf{m m} / \text { det })\end{array}$} \\
\hline & $\begin{array}{c}\text { Sefalotoraks Diangkat } \\
\left({ }^{\circ}\right)\end{array}$ & $\begin{array}{c}\text { Abdomen Diangkat } \\
\left({ }^{\circ}\right)\end{array}$ & & \\
\hline 1 & 80 & 20 & 0,5 & 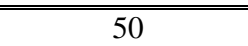 \\
\hline 2 & 50 & 10 & 0,6 & 60 \\
\hline 3 & 60 & 20 & 0,8 & 50 \\
\hline 4 & 70 & 10 & 1,0 & 40 \\
\hline 5 & 50 & 30 & 0,9 & 0 \\
\hline 6 & 70 & 25 & 1,2 & 80 \\
\hline 7 & 75 & 25 & 0,5 & 60 \\
\hline 8 & 85 & 45 & 0,6 & 90 \\
\hline 9 & 80 & 50 & 0,8 & 50 \\
\hline 10 & 75 & 25 & 0,8 & 60 \\
\hline $\begin{array}{c}\text { Rata-rata } \\
\text { SD }\end{array}$ & $\begin{array}{c}69,5 \\
12,34\end{array}$ & $\begin{array}{c}26 \\
13.08\end{array}$ & 0,77 & 60 \\
\hline
\end{tabular}




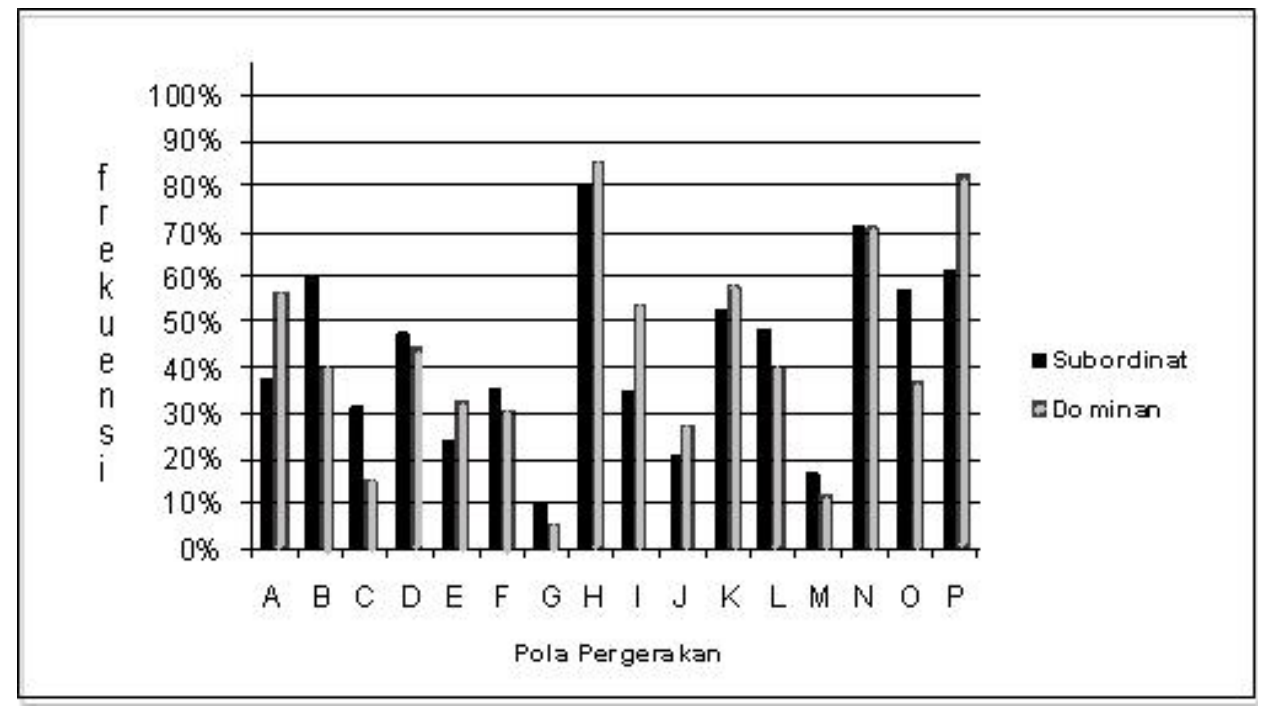

Gambar 2. Grafik persentase pola pergerakan perilaku agonistik pada pertarungan antar LAT.

\begin{tabular}{|c|c|c|c|c|c|c|c|c|c|c|c|c|c|c|c|c|}
\hline & A1 & B1 & $\mathrm{C} 1$ & D1 & E1 & F1 & G1 & H1 & I1 & $\mathrm{J} 1$ & K1 & L1 & M1 & N1 & O1 & P1 \\
\hline A2 & 0.08 & 0.15 & 0.04 & 0.01 & 0.02 & 0 & 0 & 0 & 0 & 0 & 0.05 & 0.02 & 0 & 0 & 0 & 0.01 \\
\hline B2 & 0.23 & 0.03 & 0 & 0.02 & 0.01 & 0.01 & 0.01 & 0.16 & 0.06 & 0.05 & 0 & 0.01 & 0 & 0 & 0 & 0.02 \\
\hline $\mathrm{C} 2$ & 0.12 & 0 & 0.03 & 0 & 0 & 0 & 0 & 0.01 & 0.13 & 0.02 & 0 & 0 & 0 & 0.01 & 0 & 0 \\
\hline D2 & 0.04 & 0.02 & 0.01 & 0.22 & 0.01 & 0 & 0 & 0.08 & 0.05 & 0.01 & 0 & 0.04 & 0 & 0 & 0 & 0 \\
\hline E2 & 0.03 & 0 & 0 & 0.02 & 0.04 & 0 & 0.02 & 0.02 & 0.02 & 0.01 & 0.02 & 0.01 & 0 & 0.02 & 0 & 0.03 \\
\hline F2 & 0 & 0.01 & 0 & 0 & 0.04 & 0.2 & 0 & 0.01 & 0.03 & 0 & 0.02 & 0 & 0.04 & 0 & 0 & 0.01 \\
\hline G2 & 0 & 0.02 & 0 & 0 & 0.06 & 0 & 0 & 0 & 0 & 0 & 0.01 & 0.01 & 0 & 0 & 0 & 0 \\
\hline $\mathrm{H} 2$ & 0 & 0.12 & 0 & 0.08 & 0.02 & 0.01 & 0 & 0.06 & 0.04 & 0.01 & 0.38 & 0.08 & 0 & 0 & 0 & 0.01 \\
\hline $\mathrm{I} 2$ & 0 & 0.03 & 0.07 & 0.03 & 0 & 0.01 & 0 & 0.02 & 0.11 & 0.04 & 0.04 & 0 & 0 & 0 & 0 & 0 \\
\hline $\mathrm{J} 2$ & 0.01 & 0.01 & 0 & 0 & 0 & 0 & 0 & 0.01 & 0.02 & 0.04 & 0.06 & 0.01 & 0.05 & 0 & 0 & 0 \\
\hline K2 & 0.03 & 0 & 0 & 0 & 0.02 & 0.01 & 0 & 0.42 & 0.03 & 0.02 & 0 & 0 & 0 & 0 & 0 & 0 \\
\hline $\mathrm{L} 2$ & 0.02 & 0.01 & 0 & 0.06 & 0.09 & 0 & 0.03 & 0.05 & 0.01 & 0.02 & 0 & 0.2 & 0 & 0 & 0 & 0 \\
\hline M2 & 0 & 0 & 0 & 0 & 0 & 0.07 & 0 & 0 & 0.01 & 0.03 & 0 & 0.02 & 0.03 & 0 & 0 & 0.01 \\
\hline $\mathrm{N} 2$ & 0 & $\overline{0}$ & 0 & $\overline{0}$ & 0 & 0 & 0 & 0 & 0 & 0 & 0 & 0 & 0 & 0.68 & 0 & 0.03 \\
\hline $\mathrm{O} 2$ & 0 & 0 & 0 & 0 & 0 & 0 & 0 & 0 & 0 & 0 & 0 & 0 & 0 & 0 & 0 & 0.58 \\
\hline $\mathrm{P} 2$ & 0.01 & 0.01 & 0 & 0.01 & 0.02 & 0 & 0 & 0.02 & 0.03 & 0.02 & 0 & 0 & 0 & 0 & 0.37 & 0.13 \\
\hline
\end{tabular}

Gambar 3. Matriks Jaccard similarity pada 10 pasang LAT yang bertarung, A1 s.d P1 pola pergerakan pada hewan dominan, A2 s.d P2 pola pergerakan pada hewan subordinat. Besar nilai menunjukkan probabilitas bahwa ada dua aksi yang dilakukan bersamaan oleh hewan uji pada saat bertarung dalam interval waktu satu detik.

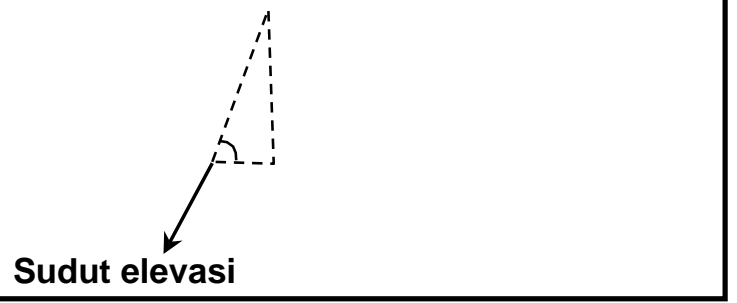

Gambar 4. Sefalotoraks diangkat membentuk sudut elevasi terhadap abdomen rata-rata $69,5^{\circ}$ pada pertarungan antar LAT Cherax quadricarinatus. 


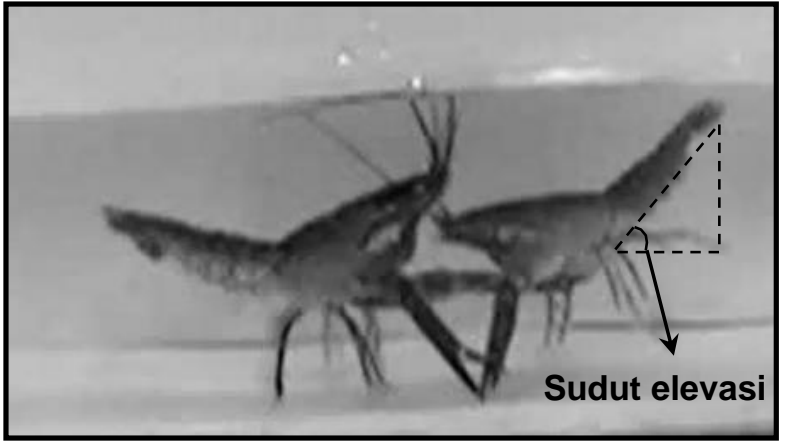

Gambar 5. Abdomen diangkat membentuk sudut elevasi terhadap pangkal sefalotoraks rata-rata $26^{\circ}$ pada pertarungan antar LAT Cherax quadricarinatus.

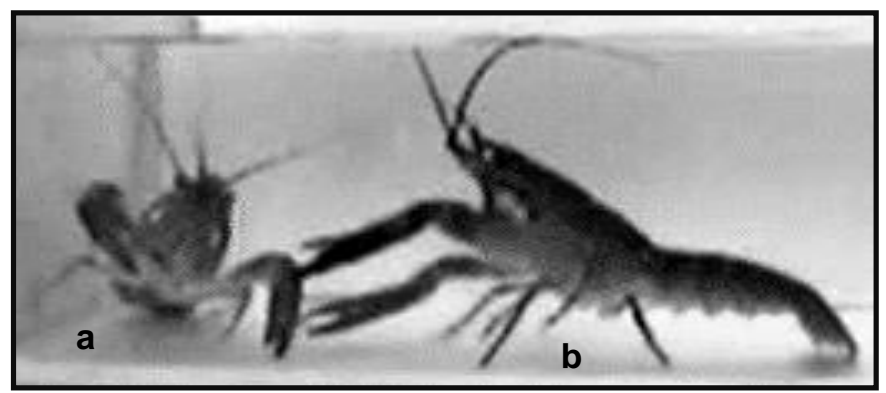

Gambar 6. Hewan yang kalah (subordinat) berperilaku tunduk (submissive) (a) ketika didekati oleh pemenang yang menunjukkan perilaku agonistik (b).

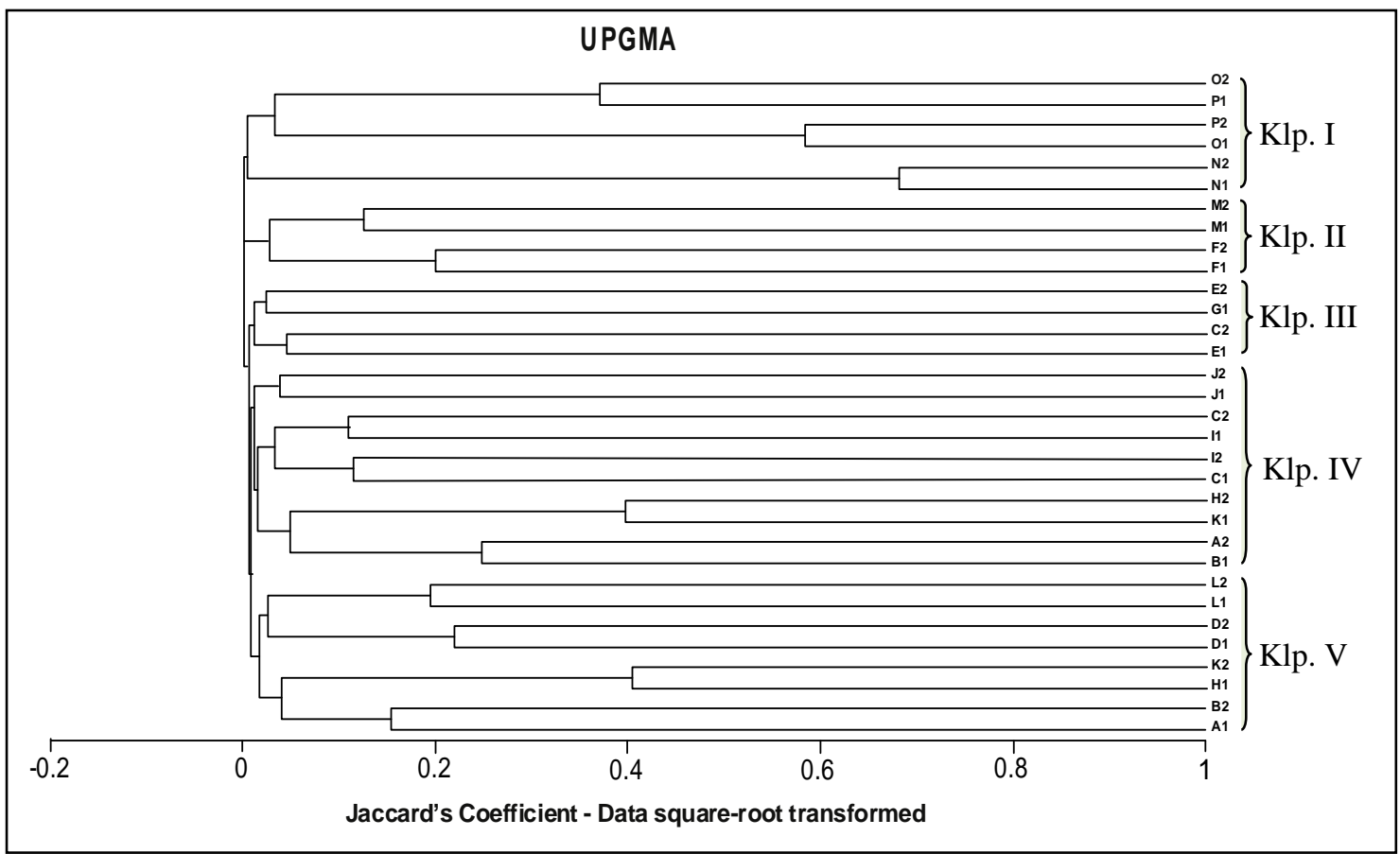

Gambar 7. Dendogram pola pergerakan perilaku agonistik pada pertarungan antar LAT (Klp. $=$ kelompok). 


\section{Simpulan}

Berdasarkan hasil penelitian dapat disimpulkan bahwa pola pergerakan agonistik LAT bertarung dengan spesies yang sama (conspecifics bouts) terdapat pola pergerakan yang sering dilakukan bersamaan oleh kedua hewan yang sedang bertarung dengan tingkat kesamaan yang tinggi, yakni perilaku: antena diangkat lurus ke atas $(\mathrm{N} 1, \mathrm{~N} 2)=0,68$; menangkis dan mencambuk lawan dengan antena $(\mathrm{P} 1, \mathrm{O} 2)=0,58$,

Pola perilaku agonistik pada pertarungan antar LAT dapat dikelompokkan ke dalam lima kelompok yaitu Kelompok I (Mengancam); Kelompok II (Mengatur strategi); Kelopok III (Menguji kemampuan lawan); Kelompok IV (Bertarung) dan Kelompok V (Menghindar dan bertahan).

\section{Ucapan Terima Kasih}

Terima kasih kami ucapkan kepada Direktorat Riset dan Pengabdian Masyarakat Universitas Indonesia (DRPM UI) yang telah membiayai penelitian kami dan Mila Novita, MSi yang telah membantu dalam pengolahan data.

\section{Daftar Pustaka}

Alonso, F. dan Martinez, R. 2006. Shelter competition between two invasive crayfish species: a laboratory study. Bull. Fr. Pêche Piscic., 380: 1121-1132.

Bergman, D.A. dan Moore, P.A. 2003. Field Observations of Intraspecific Agonistic Behaviour of Two Crayfish Species, Orconectes rusticus and Orconectes virilis, in Different Habitats. Biology Bull., 205: 26-35.

Bergman, D.A., Kozlowski, C.P., Mcintyre, J.C., Huber, R., Daws, A.G. dan Moore, P.A. 2003. Temporal Dynamics and Communication of Winer-effects in The Crayfish. Orconectes rusticus, Behavoiur, 140: 805-825.

Breithaupt, T., Schmitz, B. dan Tautz, J. 1995. Hydrodynamic Orientation of Crayfish (Procambarus clarkii) to Swimming Fish Prey. J. of Comparative Physiology, A (177): 481-491.
Breithaupt, T. dan Eger, P. 2002. Urine Makes the Difference: Chemical Communication in Fighting Crayfish Made Visible. J. of Experimental Biology, 205: 1221-1231.

Correia, A.M. 2003. Food Choice by The Introduced Crayfish Procambarus clarkia. Annales Zoologici Fennici, 40: 517-528.

Goesmann, C., Hemerlijk, C. dan Huber, R. 2000. The Formation and Maintenance of Crayfish Hierarchies: Behavioral and Self-structuring Properties. Behaviour Ecology Sociobiology, 48: 418-428.

Griffiths, S.W., Collen, P. dan Armstrong, D. 2004. Competition for Shelter Among Over-wintering Signal Crayfish and Juvenile Atlantic Salmon. J. of Fish Biology, 65: 436-447.

Herberholtz, J., Sen, M.M. dan Edwards, D.H. 2003. Parallel Changes in Agonistic and Nonagonistic Behaviors during Dominance Hierarchy Formation in Crayfish. J. of Comparative Physiology, A (169): 321-325.

Herberholz, J., Mccurdy, C. dan Edwards, D.H. 2007. Direct Benefits of Social Dominance in Juvenile Crayfish. Biology Bull., 213: 21-27.

Hill, A.M. dan Lodge, D. 1999. Replacement of Resident Crayfishes by an Exotic Crayfish: The Roles of Competition and Predation. Ecological Applications, 9: 678-690.

Huber, R. dan Kravitz, E.A. 1995. A Quantitative Analysis of Agonistic Behavior American Lobster (Homarus americanus L.). Original Paper, Harvard Medical School, Departement of Neurobiology, Boston, Mass., USA; 46: 72-83.

Huxley, T.H. 1977. The Crayfish, an Introduction to The Study of Zoology. The International Scientific Series, Cambridge. (http://www2.biology. ualberta.ca/palmer/thh/crayfish.htm).

Jones, C.M. 1998. Redclaw crayfish, The New Rural Industries A Handbook for Farmers and Investors,http://www.rirdc.gov.au/pub/handboo k/redclaw.html

Nakata, K. dan Goshima, S. 2003. Competition for Shelter of Preferred Sizes Between The Native Crayfish Species Cambaroides japonicus and The Alien Crayfish Species Pasifastacus leniusculus in Japan in Relation to Prior Residence, Sex Difference, and Body Size. J. of Crustacean Biology, 23 (4): 897-907.

Olsson, K. 2005. The Importance of Predation, Cannibalism and Resources for Production and Abundance of Crayfish. Introductory paper No. 164 Department of Ecology Institute of Limnology Lund University Lund: $42 \mathrm{hlm}$. 
Rabalais, M.R. dan Magoulick, D.D. 2006. Is Competition with The Invasive Crayfish Orconectes neglectus chaenodactylus Responsible for the Displacement of The Native Crayfish Orconectes eupunctus?. Biological invasions, 8: 1039-1048.

Smith, M.R. dan Dunham, D.W. 1995. Antennae Mediate Agonistic Physical Contact in The Crayfish Orconectes rusticus (Girard, 1852) (decapoda, cambaridae). Departement of Zoology, university of Toronto, Toronto: 668-675.
Tautz, J. 1987. Water Vibration Elicits Active Antennal Movements in The Crayfish, Orconectes limosus. Animal Behavior, 35: 748-754.

Usio, N., Konishi, M. dan Nakano, S. 2001. Species Displacement Between an Introduced and a 'vurnurable' Crayfish: The Role of Aggressive Interactions and Shelter Competition. Biological Invasions, 3: 179-185.

Wilkens, L.A., Schmitz, B. dan Herrnkind, W.F. 1996 Antenal Responses to Hydrodynamic and Tactile Stimuli in The Spiny Lobster Panulirus argus. Biology Bull., 191: 187-198. 